\title{
Bone mineral density in Brazilian men 50 years and older
}

C.A.F. Zerbini ${ }^{1}$, M.R.O. Latorre', P.C. Jaime2,

T. Tanaka² and M.G.B. Pippa ${ }^{1}$

\author{
'Departamento de Reumatologia, Hospital Heliópolis, São Paulo, SP, Brasil \\ 2Departamento de Epidemiologia, Faculdade de Saúde Pública, \\ Universidade de São Paulo, São Paulo, SP, Brasil
}

\section{Correspondence \\ C.A.F. Zerbini \\ R. João Moura, 647 , Suite 64 \\ 05412-911 São Paulo, SP \\ Brasil \\ Fax: + 55-11-852-4105 \\ E-mail: criszerb@uol.com.br \\ Publication supported by FAPESP.}

Received April 24, 2000

Accepted September 13, 2000

\section{Abstract}

Bone mineral density (BMD) in the lumbar spine (LSBMD), femoral neck (FNBMD) and whole body (WBBMD) and whole body tissue composition were evaluated in 288 Brazilian men 50 years and older, $80 \%$ white and $20 \%$ Mulattoes. Age was inversely correlated with WBBMD $(r=-0.20)$ and FNBMD $(r=-0.21)$ but not with LSBMD ( $r$ $=0.03$ ). Body mass index and weight showed a strong positive correlation with WBBMD $(r=0.48$ and 0.54$), \operatorname{LSBMD}(r=0.37$ and $0.45)$ and FNBMD ( $r=0.42$ and 0.48$)$. Correlation with height was positive but weaker. No significant bone loss at the lumbar spine level was observed as the population aged. FNBMD and WBBMD decreased significantly only in the last decade (age 70-79) studied. BMD was higher for Brazilian men as compared to Brazilian women at all sites. No significant differences were observed between Brazilian and the US/European male population for BMD in the femoral neck. BMD measured by dual-energy X-ray absorptiometry in South American men is reported here for the first time. A decrease in FNBMD was detected only later in life, with a pattern similar to that described for the US/European male population.
Low bone mass is the most important predictor of fragility fracture. Other risk factors such as low body weight and a positive maternal history of fracture may be predictive of fragility fracture but they are not as objectively quantifiable as bone mass measurements. Bone mineral density (BMD) has been measured with good precision for the purpose of identifying asymptomatic individuals at risk for fracture but factors such as ethnic variability and environmental diversity preclude the use of a single reference data base (1). Bone measurements may vary among people of different racial background

\section{Introduction}

\section{Key words}

- Bone mineral density

- O steoporosis

- Epidemiology living in specific geographic areas with differences in climate, exposure to sunlight and dietary habits (2-6). A contribution by the genetic potential to variability in bone mass may be observed comparing measurements in people of African origin and Caucasians. Its well known that, even when matched for age and weight, blacks attain a higher peak bone mass, have higher bone density and fewer osteoporotic fractures than whites $(7,8)$. Environmental factors may explain the lower bone densities found in Japan-born immigrants when compared to siblings of Japanese immigrants born in the United States (9). These data show the necessity to establish reference data for bone mass measure- 
ments and also patterns of bone loss for each particular population in order to identify pathologic deviations and indicate therapeutic interventions.

The epidemiology of osteoporosis in South America is incomplete since it has been studied in only a few areas and only in women. Available data have been summarized by Mautalen and Pumarino (10). Although it has been established that bone mass for white women at the time of menopause in São Paulo (Brazil) is very similar to values for white women in the US (11) there are no bone mass measurement studies in the normal male population. This would not be a surprise since osteoporosis research has been focused on the group at highest risk of osteoporotic fracture, i.e., white women. Only in recent years has it been recognized that fractures are common and osteoporosis in men is also a public health problem (12-14).

A large study conducted in the US, the Third National Health and Nutrition Examination Survey (NHANES III), estimated that $1-4 \%$ of men have osteoporosis and $15-33 \%$ have osteopenia based on World Health Organization female cutoffs for BMD at the femoral neck level (15).

A later pattern of bone loss and also a lesser loss of cortical bone in healthy men as compared to healthy women have been well documented $(16,17)$. The incidence of frac-

\begin{tabular}{|c|c|c|c|c|c|}
\hline Characteristics & Mean & SD & Median & Minimum & Maximum \\
\hline Age & 62.5 & 7.9 & 61.0 & 50 & 79 \\
\hline \multicolumn{6}{|l|}{ Body size } \\
\hline Weight (kg) & 73.0 & 12.5 & 71.6 & 42.1 & 116.5 \\
\hline Height (m) & 1.65 & 6.5 & 1.65 & 1.45 & 1.84 \\
\hline BMI $\left(\mathrm{kg} / \mathrm{m}^{2}\right)$ & 26.6 & 3.9 & 26.2 & 15.5 & 41.8 \\
\hline \multicolumn{6}{|l|}{$\operatorname{BMD}\left(\mathrm{g} / \mathrm{cm}^{2}\right)$} \\
\hline Lumbar spine $\left(L_{2}-L_{4}\right)$ & 1.169 & 0.191 & 1.163 & 0.713 & 1.988 \\
\hline Femoral neck & 0.916 & 0.146 & 0.918 & 0.538 & 1.393 \\
\hline Total & 1.145 & 0.104 & 1.149 & 0.819 & 1.394 \\
\hline Bone mineral content $(\mathrm{g})$ & $2,736.1$ & 424.5 & $2,740.0$ & $1,351.0$ & $4,364.0$ \\
\hline
\end{tabular}

tures due to minimal-to-moderate trauma also occurs later in life in men $(18,19)$.

The objective of this study was to obtain normal reference data for vertebral and proximal femur bone density in men 50 years and older living in an area of southern Brazil and to observe the pattern of bone loss with age. Comparisons with female Brazilian and US/ European male populations were also made.

\section{Patients and Methods}

We recruited 357 healthy male subjects 50 years and older, all residents of São Paulo city (southwestern Brazil) from among husbands whose wives were sent by their primary care physicians for a bone densitometry and we also advertised in newspapers. This cross-sectional study was part of a larger study designed to determine the relationship between body composition and bone mass in older men. All subjects were submitted to a medical interview including a food and beverage intake questionnaire, smoking habits and medication use. Written informed consent was obtained from all subjects. We measured weight $(\mathrm{kg})$ with a standardized balance-beam scale and height (m) with a stadiometer and calculated the body mass index (BMI) as the ratio of weight $(\mathrm{kg})$ to height $\left(\mathrm{m}^{2}\right)$.

BMD in the anteroposterior lumbar spine $\mathrm{L}_{2}-\mathrm{L}_{4}$, femoral neck and whole body and whole body soft tissue composition were measured with a Lunar dual-energy X-ray absorptiometer (DXA) (3.6z software; Lunar Corp., Madison, WI, USA). We report bone content in grams and BMD in $\mathrm{g} / \mathrm{cm}^{2}$. We excluded any subjects whose whole body was not fully visible within the scan region and those who had $>40 \%$ body fat.

The coefficients of variation for DXA measures were $1.5 \%$ for lumbar spine and femoral neck BMDs and $0.6 \%$ for whole body BMD.

After application of the exclusion criteria the number of participants was reduced to 
288 males, $79.86 \%$ of them white and $20.14 \%$ Mulatto. There were no Orientals in our sample.

\section{Statistical analysis}

The Kruskal-Wallis test was used to compare BMDs among different decades of life. Pearson's correlation coefficients were calculated to analyze the association between bone mass/bone density variables and body size measurements. The Student $t$-test was used to examine possible differences between Brazilian and US/European male populations for the measured variables and also between Brazilian female (11) and male populations. The effective $\mathrm{P}$ value for observations to be considered statistically significant was 0.05 . Data were analyzed using the SPSS statistical software system.

\section{Results}

The characteristics of the 288 men are shown in Table 1. Their mean age was 62.5 years, $79.86 \%$ were white and $20.14 \%$ were Mulattoes. Their mean BMI was $26.6 \mathrm{~kg} / \mathrm{m}^{2}$, mean weight $73 \mathrm{~kg}$, and mean height $1.65 \mathrm{~m}$.

A correlation matrix is provided in Table 2, which indicated a negative association between BMD and age at all skeletal sites except the lumbar spine. These associations were significant for the femoral neck $(\mathrm{P}<0.001)$ and whole body $(\mathrm{P}=0.001)$ but not for the spine. Height associations were weaker and less consistent. BMI and weight were significantly correlated with BMDs at all sites showing similar Pearson's coefficients. When subjects were stratified by decade (Table 3) significant decrements in weight and height were observed only in the eighth decade (age 70-79). These decrements kept BMI unchanged with age.

Body size comparisons between Brazilian male and female (11) populations are shown in Table 4. Women had a significant increase in BMI with age due to decreasing
Table 2 - Correlations between body size and bone mass variables ( $\mathrm{N}=288$ men).

$r=$ Pearson's correlation coefficient; BMI = body mass index; WBBMC $=$ whole body bone mineral content; WBBMD = whole body bone mineral density; LSBMD = lumbar spine bone mineral density; FNBMD = femoral neck bone mineral density.

\begin{tabular}{lllll}
\hline Variables & WBBMC & WBBMD & LSBMD & FNBMD \\
\hline Age $(r)$ & -0.19 & -0.20 & 0.03 & -0.21 \\
P & $(0.001)$ & $(0.001)$ & $(0.631)$ & $(<0.001)$ \\
Weight $(r)$ & 0.72 & 0.54 & 0.45 & 0.48 \\
P & $(<0.001)$ & $(<0.001)$ & $(<0.001)$ & $(<0.001)$ \\
Height $(r)$ & 0.57 & 0.26 & 0.25 & 0.24 \\
P & $(<0.001)$ & $(<0.001)$ & $(<0.001)$ & $(<0.001)$ \\
BMI $(r)$ & 0.52 & 0.48 & 0.37 & 0.42 \\
P & $(<0.001)$ & $(<0.001)$ & $(<0.001)$ & $(<0.001)$
\end{tabular}

Table 3 - Clinical and demographic characteristics of 288 healthy Brazilian men stratified by decade.

$\mathrm{P}<0.05$ for $\mathrm{a} \times \mathrm{c}, \mathrm{b} \times \mathrm{c}, \mathrm{d} \times \mathrm{f}$, and e $\mathrm{x}$ (Kruskal-Wallis test with correction). BMI, Body mass index.

\begin{tabular}{lrlll}
\hline Age (years) & $\mathrm{N}$ & Weight $(\mathrm{kg})$ & Height $(\mathrm{m})$ & BMI $\left(\mathrm{kg} / \mathrm{m}^{2}\right)$ \\
\hline $50-59$ & 122 & $74.2 \pm 13.4^{\mathrm{a}}$ & $1.66 \pm 6.2^{\mathrm{d}}$ & $26.7 \pm 4.2^{\mathrm{g}}$ \\
$60-69$ & 106 & $73.8 \pm 11.3^{\mathrm{b}}$ & $1.65 \pm 7.0^{\mathrm{e}}$ & $26.8 \pm 3.7^{\mathrm{h}}$ \\
$70-79$ & 60 & $69.2 \pm 12.0^{\mathrm{c}}$ & $1.62 \pm 5.8^{\mathrm{f}}$ & $26.3 \pm 4.1^{\mathrm{i}}$
\end{tabular}

Table 4 - Comparison between Brazilian male $(\mathrm{M})$ and female $(\mathrm{F})^{*}$ populations for weight, height and body mass index (BMI) stratified by decade.

Data were analyzed statistically by the Student t-test. *Brazilian female population from Ref. 11.

\begin{tabular}{lllll}
\hline Age (years) & $\mathrm{N}$ & Weight $(\mathrm{kg})$ & Height $(\mathrm{m})$ & BMI $\left(\mathrm{kg} / \mathrm{m}^{2}\right)$ \\
\hline $50-59$ & $M(122)$ & $74.2 \pm 13.4^{\mathrm{a}}$ & $1.66 \pm 0.1^{\mathrm{c}}$ & $26.7 \pm 4.2^{\mathrm{e}}$ \\
& $\mathrm{F} \mathrm{(138)}$ & $64.0 \pm 8.1^{\mathrm{b}}$ & $1.58 \pm 0.1^{\mathrm{d}}$ & $25.5 \pm 3.1^{\mathrm{f}}$ \\
$60-69$ & $\mathrm{M}(106)$ & $73.8 \pm 11.3^{\mathrm{g}}$ & $1.65 \pm 0.1^{\mathrm{i}}$ & $26.8 \pm 3.7^{\mathrm{k}}$ \\
& $\mathrm{F}(61)$ & $63.4 \pm 8.1^{\mathrm{h}}$ & $1.55 \pm 0.1^{\mathrm{j}}$ & $26.4 \pm 3.5^{\mathrm{I}}$ \\
$70-79$ & $\mathrm{M} \mathrm{(60)}$ & $69.2 \pm 12.0^{\mathrm{m}}$ & $1.62 \pm 0.1^{\mathrm{o}}$ & $26.3 \pm 4.1^{\mathrm{q}}$ \\
& $\mathrm{F}(18)$ & $64.1 \pm 7.7^{\mathrm{n}}$ & $1.54 \pm 0.1^{\mathrm{p}}$ & $27.0 \pm 3.1^{\mathrm{r}}$ \\
\hline
\end{tabular}

$\begin{array}{lll}\mathrm{a} \times \mathrm{b}: P=0.009 & g \times h: P<0.001 & m \times n: P<0.001 \\ c \times d: P=0.494 & i \times j: P<0.001 & o \times p: P<0.001 \\ \text { exf: } P=0.506 & k \times l: P=0.094 & q \times r: P<0.0019\end{array}$


height and increasing weight. These changes led to a significantly higher female BMI than in males in the eighth decade $(\mathrm{P}<0.001)$. A cross-calibration between equipment used by us and those used in the female study was performed before the beginning of the present study in order to allow both centers to

Table 5 - Mean bone mineral density of lumbar spine, femoral neck and whole body of 288 healthy Brazilian men 50 years and older.

$\mathrm{P}<0.05$ for $\mathrm{d} \times \mathrm{f}$, e $\times f, \mathrm{~g} \times \mathrm{i}$, and $\mathrm{h} \times \mathrm{i}$ (Kruskal-Wallis test with correction).

\begin{tabular}{lrrrc}
\hline Age (years) & $\mathrm{N}$ & Spine $\left(\mathrm{g} / \mathrm{cm}^{2}\right)$ & Neck $\left(\mathrm{g} / \mathrm{cm}^{2}\right)$ & Whole body $\left(\mathrm{g} / \mathrm{cm}^{2}\right)$ \\
\hline $50-59$ & 122 & $1.157 \pm 0.20^{\mathrm{a}}$ & $0.939 \pm 0.15^{\mathrm{d}}$ & $1.160 \pm 0.17 \mathrm{~g}$ \\
$60-69$ & 106 & $1.187 \pm 0.17^{\mathrm{b}}$ & $0.922 \pm 0.16^{\mathrm{e}}$ & $1.149 \pm 0.10^{\mathrm{h}}$ \\
$70-79$ & 60 & $1.171 \pm 0.20^{\mathrm{C}}$ & $0.862 \pm 0.12^{\mathrm{f}}$ & $1.114 \pm 0.10^{\mathrm{i}}$
\end{tabular}

Table 6 - Comparison of Brazilian male $(\mathrm{M})$ and female $(\mathrm{F})^{*}$ populations for lumbar spine and femoral neck bone mineral densities stratified by decade.

Data were analyzed statistically by the Student t-test. $P<0.0001$ for $a \times b, c \times d$, e xf, $\mathrm{g} \times \mathrm{h}$, and i $\mathrm{j}$. $\mathrm{P}<0.0007$ for $\mathrm{k} \times \mathrm{l}$. * Brazilian female population from Ref. 11 .

\begin{tabular}{llll}
\hline Age (years) & \multicolumn{1}{c}{$\mathrm{N}$} & Spine $\left(\mathrm{g} / \mathrm{cm}^{2}\right)$ & Femur $\left(\mathrm{g} / \mathrm{cm}^{2}\right)$ \\
\hline $50-59$ & $M(122)$ & $1.157 \pm 0.20^{\mathrm{a}}$ & $0.939 \pm 0.16^{\mathrm{g}}$ \\
& $\mathrm{F} \mathrm{(138)}$ & $1.010 \pm 0.14^{\mathrm{b}}$ & $0.830 \pm 0.10^{\mathrm{h}}$ \\
$60-69$ & $\mathrm{M} \mathrm{(106)}$ & $1.187 \pm 0.17^{\mathrm{c}}$ & $0.922 \pm 0.13^{\mathrm{i}}$ \\
& $\mathrm{F} \mathrm{(61)}$ & $0.940 \pm 0.14^{\mathrm{d}}$ & $0.770 \pm 0.11^{\mathrm{j}}$ \\
$70-79$ & $\mathrm{M} \mathrm{(60)}$ & $1.171 \pm 0.20^{\mathrm{e}}$ & $0.862 \pm 0.12^{\mathrm{k}}$ \\
& $\mathrm{F} \mathrm{(18)}$ & $0.950 \pm 0.16^{\mathrm{f}}$ & $0.750 \pm 0.10^{\mathrm{l}}$
\end{tabular}

Table 7 - Comparison of Brazilian and US/European* male populations for lumbar spine and femoral neck bone mineral densities $\left(\mathrm{g} / \mathrm{cm}^{2}\right)$ stratified by decade.

Data were analyzed statistically by the Student t-test. No statistical differences were detected between measurements except $\mathrm{c} x \mathrm{~d}(\mathrm{P}=0.02)$. * Lunar reference data from Ref. 21.

\begin{tabular}{lcccc}
\hline Country & Site & $50-59$ years & $60-69$ years & $70-79$ years \\
\hline Brazil & Spine & $1.157 \pm 0.20^{\mathrm{a}}$ & $1.187 \pm 0.17^{\mathrm{c}}$ & $1.171 \pm 0.20^{\mathrm{e}}$ \\
& & $(\mathrm{N}=122)$ & $(\mathrm{N}=106)$ & $(\mathrm{N}=54)$ \\
US/Europe & & $1.145 \pm 0.240^{\mathrm{b}}$ & $1.157 \pm 0.24^{\mathrm{d}}$ & $1.173 \pm 0.24^{\mathrm{f}}$ \\
& & $(\mathrm{N}=250)$ & $(\mathrm{N}=400)$ & $(\mathrm{N}=330)$ \\
Brazil & Neck & $0.939 \pm 0.16 \mathrm{~g}$ & $0.922 \pm 0.13^{\mathrm{i}}$ & $0.862 \pm 0.12^{\mathrm{k}}$ \\
& & $(\mathrm{N}=122)$ & $(\mathrm{N}=106)$ & $(\mathrm{N}=54)$ \\
US/Europe & & $0.956 \pm 0.26^{\mathrm{h}}$ & $0.909 \pm 0.26$ & $0.876 \pm 0.26^{\mathrm{l}}$ \\
& & $(\mathrm{N}=319)$ & $(\mathrm{N}=428)$ & $(\mathrm{N}=344)$
\end{tabular}

participate in a multicenter trial already published elsewhere (20).

No significant bone loss was observed at the lumbar spine level as the study population aged (Table 5). Artifacts such as osteophytes or extravertebral calcification, which are common in older men, may have influenced lumbar spine BMD results. Femoral neck and whole body BMDs did not change significantly between the sixth decade (age 50-59) and the seventh decade (age 60-69). When these two decades were compared with the last decade (age 70-79) BMD values showed a significant decrease, disclosing a later pattern of bone loss in the mainly predominant cortical bone areas. Brazilian women had lower BMDs at all sites and also an earlier pattern of bone loss when compared to men (Table 6).

No significant differences were observed between Brazilian and US/European (21) older male populations for BMD at all skeletal sites except for lumbar spine in the seventh decade (Table 7). Neither population showed a decrease in bone mass at the lumbar spine level with age. At the femoral neck level, bone density decreased linearly with age for all subjects.

\section{Discussion}

The present results show normative data for BMD and the pattern of bone loss for Brazilian men 50 years and older living in São Paulo city (southwestern Brazil).

Brazil is a large country with a wide variety of environmental conditions. The Brazilian male population shows ethnic multiplicity and is characterized by an interracial mixing rarely seen in other countries. Taking into account these factors the database obtained in our study may not be representative of the entire Brazilian male population and therefore our normative data should be used only for a population sharing the same genetic potential and living under similar environmental conditions. One limitation 
of our study was the recruitment of volunteers. The study sample was not population based but recruited from husbands whose wives were admitted for bone densitometry or through newspaper advertisements. It is possible that this may introduce a selection bias focusing on the wealthier and better educated part of the population or alternatively on those who through life style or living conditions are more prone to osteoporosis.

To our knowledge, this is the first study of BMD in a large South American male population using DXA measurements. Before our study Pumarino et al. (22) published BMD data for the normal male population of Santiago (Chile). Unfortunately, the determinations were performed with a different type of equipment (Norland 2000) using a gadolinium-153 source. The different calibration of the equipment and doubts involving the analysis of values from different scales prevented a comparison. In the present study body size (weight and BMI) was strongly correlated with BMD at the spine, femoral neck and whole body levels. BMD decrements by age were observed at all skeletal sites, except the spine. The lack of association between spinal BMD and age has been observed in other studies in men using bone absorptiometry (22-25). This may reflect degenerative changes of the spine due to spondylosis deformans or vascular calcifications, although one study (26) demonstrated stability of $\mathrm{L}_{2}-\mathrm{L}_{4}$ BMD with age in men after radiographic exclusion of osteophytes. A recent study has used lumbar spine BMD successfully to correlate bone loss with vertebral body size in a small male population (27). Trabecular bone loss with aging has been evidenced by the technique of quantitative computed tomography (QCT) in the male spine $(28,29)$. Probably the use of lateral QCT and DXA measurements may provide a more accurate assessment of spinal bone mass changes in men (30).

Significant weight loss was associated with significant decrements in whole body and femoral neck BMDs in the eighth decade. Weight has been correlated with bone mass variations showing that heavier men have greater BMD and that weight loss is associated with bone loss with aging $(31,32)$. Mazess et al. (26) found a low but also significant correlation of lumbar spine and femoral neck BMDs with body weight in males. It should be taken into account, however, that BMD is influenced by skeletal size since it is not corrected for variations in the third dimension. Since body weight and skeletal size are related this may explain some of the relations described. Longitudinal studies are needed to confirm our results.

Some controversy still remains over the continuation and pattern of bone loss in the very elderly population. Although some studies suggest that cortical bone loss may cease in old age $(33,34)$, our cross-sectional study suggests that cortical bone loss, which predominates at femoral neck and whole body sites, may continue in old males. A crosssectional study may have some limitations due to a possible cohort effect, but the same pattern of bone loss was also observed in the longitudinal Framingham Osteoporosis Study (35).

In the present study BMD at the lumbar spine and femoral neck level was higher for men than for women in all decades. Vertebral BMD continued to decrease with age in the sample of women used for comparison (11) but not for men. BMD at the femoral neck level decreased for both sexes with age but reduction was lesser and later for men. The Framingham Study (35) found no difference between sexes for BMD at the forearm or proximal femur level. Mazess et al. (26) found no differences in BMD at the spine, femoral neck or trochanter level when comparing men and women aged 70 years and older. Blunt et al. (36) measured BMD at the spine, hip, midshaft and ultradistal radius level in a large population of men and women aged 50-98 years. In their study mean BMD 
levels decreased significantly with age at all sites except the male spine and bone loss was significantly higher in women except for the ultradistal radius. Differences among crosssectional studies may be elucidated in future prospective studies.

The similar values for BMD at the lumbar spine and femoral neck level between Brazilian and US male populations allow the use of the same reference data for both. An exception was the lumbar spine BMD in the seventh decade (ages 60-69). This may be due to osteophytes or to an artifact effect as discussed earlier.

In the present study we cannot exclude cohort effects such as socioeconomic status, lifetime exercise patterns or nutritional habits. A survival bias may also have occurred since we made bone measurements only in the individuals able to come to the outpatient clinic. It is possible that the total elderly male population may have lower BMD levels.

We have described BMD data for a predominantly Caucasian healthy Brazilian male population 50 years and older. Our crosssectional data indicate that BMD levels in cortical areas decline with age in men and this occurs later in life than for women. These observations suggest that interventions directed at preserving bone mass may be helpful in elderly men. Population screening for osteoporosis in men may be considered at the beginning of the eighth decade when there is a significant bone loss in the femoral neck, probably followed by a rapid increase in age-related fractures (37).

\section{References}

1. DeSimone DP, Stevens J, Edwards J, Shary J , Gordon L \& Bell NH (1989). Influence of body habitus and race on bone mineral density of the midradius, hip, and spine in aging women. J ournal of Bone and Mineral Research, 4: 827-830.

2. Wasnich RD (1997). Epidemiology of osteoporosis in the United States of America. Osteoporosis International, 7 (Suppl 3): S68-S72.

3. Liu ZH, Zhao YL, Ding GZ \& Zhou Y (1997). Epidemiology of primary osteoporosis in China. Osteoporosis International, 7 (Suppl 3): S84-S87.

4. Rowe SM, J ung ST \& Lee J Y (1997). Epidemiology of osteoporosis in Korea. Osteoporosis International, 7 (Suppl 3): S88s90.

5. Reeve J \& Silman A (1997). Epidemiology of osteoporotic fractures in Europe: toward biological mechanisms. The European Prospective Osteoporosis Study. Osteoporosis International, 7 (Suppl 3): S78-S83.

6. Hashimoto T, Sakata K \& Yoshimura N (1997). Epidemiology of osteoporosis in J apan. Osteoporosis International, 7 (Suppl 3): S99-S102.

7. Farmer ME, White LR \& Brody J A (1984). Race and sex differences in hip fracture incidence. American J ournal of Public Health, 44: 1374-1380.
8. Luckey $M M$, Meier $D E$, Mandeli JP, DaCosta MC, Hubbard ML \& Goldsmith SL (1989). Radial and vertebral bone density in white and black women: evidence for racial differences in pre-menopausal bone homeostasis. J ournal of Clinical Endocrinology and Metabolism, 69: 762-770.

9. Yano K, Wasnich RD, Vogel J M \& Heilbrun LK (1984). Bone mineral measurements among middle-aged and elderly J apanese residents in Hawaii. American J ournal of Epidemiology, 119: 751-764.

10. Mautalen C \& Pumarino H (1997). Epidemiology of osteoporosis in South America. Osteoporosis International, 7 (Suppl 3): S73-S77.

11. Szejnfeld VL, Atra E, Baracat EC, Aldright J M \& Civitelli R (1995). Bone density in white Brazilian women: rapid loss at the time around the menopause. Calcified Tissue International, 56: 186-191.

12. Orwoll ES \& Klein RF (1995). Osteoporosis in men. Endocrine Reviews, 16: 87116.

13. Ray NF, Chan J K, Thamer M \& M elton LJ (1997). Medical expenditures for the treatment of osteoporotic features in the United States in 1995: report from the National Osteoporosis Foundation. J ournal of Bone and M ineral Research, 12: 2435.

14. Seeman E (1995). The dilemma of os- teoporosis in men. American J ournal of Medicine, 98 (Suppl 2A): 76S-86S.

15. Looker AC, Orwoll ES, J ohnston J r CC, Lindsay RL, Wahner HW, Dunn WL, Calvo MS, Harris TB \& Heyse SP (1997). Prevalence of low femoral bone density in older US adults from NHANES III. J ournal of Bone and Mineral Research, 12: 17611768.

16. Ruff CB \& Hayes WC (1988). Sex differences in age-related remodeling of the femur and tibia. J ournal of Orthopaedic Research, 6: 886-896.

17. Mosekilde L \& Mosekilde L (1990). Sex differences in age-related changes in vertebral body size, density and biochemical competence in normal individuals. Bone, 11: 67-73.

18. Donaldson LJ , Cook A \& Thomson RG (1990). Incidence of fractures in a geographically defined population. J ournal of Epidemiology and Community Health, 44: 241-245.

19. Cooper C, Atkinson EJ , O'Fallon WM \& Melton III LJ (1992). Incidence of clinically diagnosed vertebral fractures: a population-based study in Rochester, Minnesota, 1985-1989. J ournal of Bone and Mineral Research, 7: 221-227.

20. Pols HAP, Felsenberg D, Hanley DA Štepán J , Muñoz-Torres M, Wilkin TJ , Qinsheng G, Galich AM, Vandormael K, Yates 
AJ \& Stych B for the Fosamax International Trial Study Group (1999). Multinational, placebo-controlled, randomized trial of the effects of alendronate on bone mineral density and fracture risk in postmenopausal women with low bone mass: results of the FOSIT Study. Osteoporosis International, 9: 461-468.

21. Lunar reference data for normal US/Europe male population (1999). In: Favus MJ (Editor), Primer on the Metabolic Bone Diseases and Disorders of Mineral Metabolism. 4th edn. Lippincott, Philadelphia, 483.

22. Pumarino $\mathrm{H}$, Lillo $\mathrm{R}$, Oviedo $\mathrm{S} \&$ González P (1993). Densidad y contenido mineral óseo en hombres normales: medición por densitometría bifotónica. Revista Medica de Chile, 121: 1006-1011.

23. Orwoll ES, Oviatt SK, McClung MR, Deftos LJ \& Sexton G (1990). The rate of bone mineral loss in normal men and the effects of calcium and cholecalciferol supplementation. Annals of Internal Medicine, 112: 29-34.

24. Mann T, Oviatt SK, Wilson D, Nelson D \& Orwoll ES (1992). Vertebral deformity in men. Journal of Bone and Mineral Research, 7: 1259-1265.

25. Bendavid EJ , Shan J \& Barrett-Connor E (1996). Factors associated with bone mineral density in middle-aged men. J ournal of Bone and Mineral Research, 11: 11851190.
26. Mazess RB, Barden HS, Drinka PJ, Bauwens SF, Orwoll ES \& Bell NH (1990). Influence of age and body weight on spine and femur bone mineral density in US white men. J ournal of Bone and Mineral Research, 5: 645-652.

27. Vega E, Ghiringhelli G, Mautalen C, Valzacchi GR, Scaglia H \& Zylberstein C (1998). Bone mineral density and bone size in men with primary osteoporosis and vertebral fractures. Calcified Tissue International, 62: 465-469.

28. Meier DE, Orwoll ES \& J ones J M (1984). Marked disparity between trabecular and cortical bone loss with age in healthy men. Annals of Internal Medicine, 101: 605612.

29. Cann CE \& Genant HK (1982). Cross-sectional studies of vertebral mineral using quantitative computed tomography. J ournal of Computer Assisted Tomography, 6: 216-217.

30. Finkelstein J S, Cleary RL, Butler J P, Antonelli R, Mitlak BH, Deraska DJ , Zamora-Quezada J C \& Neer RM (1994). A comparison of lateral versus anterior-posterior spine dual energy X-ray absorptiometry for the diagnosis of osteopenia. J ournal of Clinical Endocrinology and Metabolism, 78: 724-730.

31. Nguyen TV, Eisman J A, Kelly PJ \& Sambrook PN (1996). Risk factors for osteoporotic fractures in elderly men. American J ournal of Epidemiology, 144: 258-
261.

32. Mussolino ME, Looker AC, Madans JH, Langlois J Á \& Orwoll ES (1998). Risk factors for hip fracture in white men: the NHANES I epidemiologic follow-up study. J ournal of Bone and Mineral Research, 13: 918-924.

33. Riggs BL, Wahner HW, Seeman E, Offord KP, Dunn WL, Mazess RB, J ohnson KA \& Melton III LJ (1982). Changes in bone mineral density of the proximal femur and spine with aging: differences between the postmenopausal and senile osteoporosis syndromes. J ournal of Clinical Investigation, 70: 716-723.

34. Mazess RB (1982). On aging bone loss. Clinical Orthopaedics, 165: 239-252.

35. Hannan MT, Felson DT \& Anderson JJ (1992). Bone mineral density in elderly men and women: results from the Framingham Osteoporosis Study. J ournal of Bone and Mineral Research, 7: 547-553.

36. Blunt BA, Klauber MR, Barrett-Connor EL $\&$ Edelstein SL (1994). Sex differences in bone mineral density in 1653 men and women in the sixth through tenth decades of life: The Rancho Bernardo Study. J ournal of Bone and Mineral Research, 9: 1333-1337.

37. Orwoll ES (1999). Osteoporosis in men. In: Favus MJ (Editor), Primer on the Metabolic Bone Diseases and Disorders of Mineral Metabolism. 4th edn. Lippincott, Philadelphia, 289-292. 